\title{
BACTERIAL DIVERSITY IN RICE-FIELD WATER IN RIO GRANDE DO SUL
}

\author{
Maria Helena Lima Ribeiro Reche ${ }^{1}$; Lídia Mariana Fiuza ${ }^{1,2 *}$ \\ ${ }^{1}$ Laboratório de Microbiologia, Universidade do Vale do Rio dos Sinos, São Leopoldo, RS, Brasil; ${ }^{2}$ EEA, Instituto Riograndense \\ do Arroz, Cachoeirinha, RS, Brasil
}

Submitted: July 22, 2003; Returned to authors for corrections: March 21, 2005; Approved: September 20, 2005

\begin{abstract}
Bacteria are the most diverse living beings on earth and only a fraction of them have been identified. This paper aims at the analysis of the diversity of mesophilic and heterotrophic bacteria found in samples of irrigation water from rice-fields areas in Rio Grande do Sul State, Brazil. Sample collection was carried out in five rice crop regions areas and followed by isolation, multiplication and bacterial characterization. The species' identification was based on biochemical tests (API-System, bioMérieux). Bacterial diversity was determined by the Shannon $\&$ Weaner and Pielou index. The results regarding bacterial diversity revealed 26 species. The most abundant representatives belonged to the Bacillus, Corynebacterium, Staphylococcus and Lactobacillus genera, homogeneously distributed in all studied rice crop areas, and in those areas corresponding to the irrigation channel and the rice growing plot as well. The water of the irrigation channel showed the greatest diversity $\left(H^{\prime}=1.00\right)$ when compared to the plot $\left(H^{\prime}=0.77\right)$. The channel also presented a more even species distribution $(\mathrm{e}=0.73)$, while the plot $(\mathrm{e}=0.59)$ had the greatest prevalence represented by the Bacillus genus. The areas and the cultivation phases did not significantly affect the bacterial diversity in the study areas $\left(\mathrm{F}_{4,12}=1.04 ; \mathrm{P}>0.05\right)$. The results showed that culture management could affect water bacterial populations.
\end{abstract}

Key words: bacteria, diversity, water, rice-field

\section{INTRODUCTION}

Microorganisms play an important role in the biosphere, such as cycling of carbon and other elements. Some bacteria carry out the biologic fixation of the atmospheric nitrogen, denitrification, sulfate reduction, methane production, biotransformation of metals and degradation of vegetal and other products residues $(1,8)$.

Bacteria are the most diverse living beings on earth and only a fraction of them has been identified (10). Microbiota found in freshwater has been going through many investigations. On the water surface, the prevalent prokaryotic mass corresponds to autotrophic and heterotrophic bacteria (11). Population density in environments with euthrofizing nutrients is regulated by factors such as photoperiod and temperature. Temperature variations are environmental factors that rule the species distribution, including microorganisms (21).
Effluent release lacking basic sanitation results in contaminated springs, with significant changes that add to the fast degradation of these environments. At present, microorganisms have been used as bioindicators to monitor the restoration of habitats (8).

In the rice agroecosystem, the microbial population of the water lamina reflects the conditions of the water source and the surrounding soil. The irrigation water from the rivers is influenced by domestic, industrial and food growing practices (20), with the later ones often leading to increase the prevalence of heavy metals in the environment (15).

Rice is one of the main cereals grown in the world, found throughout the five continents from tropical to temperate zones. Asia is responsible for more than $90 \%$ of the production (26). MERCOSUL stands out for its irrigated rice production potential. Brazil nowadays grows around 4,0-million ha of rice, with $30 \%$ of that area corresponding to the low lands near the water. In

*Corresponding Author. Mailing address: Laboratório de Microbiologia, Universidade do Vale do Rio dos Sinos, Av. Unisinos, 950, 93022-000, São Leopoldo, RS, Brasil. E-mail: fiuza@unisinos.br 
Brazil, the Rio Grande do Sul State (RS) is responsible for about $48 \%$ of the Brazilian rice production, with a rice growing area larger than 900,000 ha (9). The production indexes are similar to those of the most developed plowing fields in the world.

Rice production in $\mathrm{RS}$ also has economic and social significance. Thus, rice-fields demand managerial care, requiring an increase on quantity and quality of production, with less environmental impact. This research aimed to evaluate the bacteria diversity in water samples collected from five irrigated rice fields in $\mathrm{RS}$, through enumeration and identification of mesophilic and heterotrophic species present in irrigation channels and rice crop plots.

\section{MATERIALS AND METHODS}

\section{Experimental areas}

The experimental areas were five rice crop regions located in Rio Grande do Sul State, Brazil: the Western Border (Uruguaiana, $29^{\circ} 45^{\prime} 17^{\prime \prime S o u t h}$ latitude and $57^{\circ} 05^{\prime} 18^{\prime \prime}$ West longitude), Central Depression (Restinga Seca, 28 $13^{\circ}$ '11" South latitude and 54²0'57" West longitude), Southern Coast (Santa Vitória do Palmar, 33³1'08" South latitude and 5322'05" West longitude), Northern Coast (Torres, 29²0'07" South latitude and 4943'37" West longitude) and The Plains (Dom Pedrito, 3058' 58" South latitude and 54\%40'23" West longitude).

The water samples were collected between November 2001 and April 2002 in the five rice crop regions of RS. They were collected in duplicates, summing $10 \mathrm{sub}^{-}$samples of $100 \mathrm{~mL}$

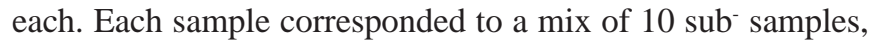
composed of 10-mL aliquots, collected along one linear meter. Immediately after collection the samples were homogenized in $100-\mathrm{mL}$ sterilized flasks and kept at $4^{\circ} \mathrm{C}$ tested in the Microbiology Laboratory of the Health Sciences Center at UNISINOS. The samples were collected in two sites, one at the irrigation channel (IC) and the other at the rice-field plot (RP). Two collections were made throughout the rice growing cycle. The first one $\left(\mathrm{P}_{1}\right)$ was obtained 15 days after the plots' irrigation, between November 2001 and February 2002 and the second one $\left(\mathrm{P}_{2}\right)$ was obtained close to harvesting or draining of plots, and finished by the end of April 2002.

\section{Bacterial isolation and multiplication}

The samples were aseptically distributed on Nutrient Agar (16) and incubated at $30^{\circ} \mathrm{C}$, in aerobic conditions, during 24 hours. Grown colonies were multiplied in nutrient broth (16) and maintained in Agar at $4^{\circ} \mathrm{C}$ and in glycerol $(10 \%)$ at $-18^{\circ} \mathrm{C}$.

\section{Bacterial characterization}

The identification of the bacterial groups in was conducted according to Buchanan et al. (4) and based on the identification key adapted from Yamaoka-Yano and Valarini (27). The specific characteristics of the isolates were determined according to
Boone and Castenholz (3). The required biochemical tests were carried out according to MacFaddin (14).

In chemosystematics, the biochemical and physiological tests were conducted using carbonated media (tests for Glucose, Lactose, Methyl Red, Voges Proskauer, Citrate, Oxidation and Fermentation) and nitrogenated multimedia (tests for Indol, Sulfidric gas, Phenylalanine-deaminase and Urease). Properties associated with cell structures, such as secreted flagella and enzymes were also investigated $(12,20)$. Gram-negative rods, mainly those belonging to the Enterobacteriaceae family, were characterized by the use of API systems (API 20 E, bioMeriéux), incubated for 18-24 hours at $37^{\circ} \mathrm{C}$. The results were interpreted, according to MacFaddin (14) and Koneman et al. (12).

\section{Statistical analysis}

The data were analyzed by Systat and Microsoft programs, using the Analysis of Factorial Variance (28) and the Single connecting method. The Percent distance index was used to measure the similarity in the composition of the species among the regions. To estimate the Shannon's \& Weaner's and Pielou's diversity indexes the following formula were used $(19,22)$ :

- Shannon's Index: $\quad(\bar{H})=-\Sigma\left(n_{i} / N\right) \log \left(n_{i} / N\right)$ ou $-\Sigma P_{i} \log P_{i}$

In which: $\mathrm{n}_{\mathrm{i}}=$ importance value for each species; $\mathrm{N}=$ total importance values and $P_{i}$ is the importance probability of each species $\left(=n_{i} / N\right)$. To compare the indexes found for the irrigation channel's and rice-field plot's treatments $\left(\mathrm{H}_{1}{ }_{1} \mathrm{e} \mathrm{H}_{2}{ }_{2}\right)$, variances of each group's data were estimated:

$$
S^{2}=\frac{\sum f_{i} \log ^{2} f_{i}-\left(\sum f_{i} \log f_{i}\right)^{2} / n}{n^{2}}
$$

The resulting values were compared through Student's $t$ test (5).

$$
\text { - Pielou's Uniformity Index: e }=\frac{\overline{\mathrm{H}}}{\log \mathrm{S}}
$$

In which: $\overline{\mathrm{H}}$ is Shannon's index and $\mathrm{S}$ is the number of species.

\section{RESULTS AND DISCUSSION}

As shown in Table 1, the bacterial isolates corresponded to 26 species. Seven species were isolated from the non-treated water of the irrigation channel, two species from the treated area, corresponding to the rice-crop plot, and 17 species came from both treatments (the irrigation channel and the rice crop plot). These results represent the addition of the initial $\left(\mathrm{P}_{1}\right)$ and final $\left(\mathrm{P}_{2}\right)$ phases of the rice crop cycle. 
Table 1. Bacterial isolates identified in water samples from five rice crop regions in Rio Grande do Sul State, Brazil.

\begin{tabular}{lccc}
\hline \multicolumn{1}{c}{ Bacteria } & $\begin{array}{c}\text { Irrigation } \\
\text { channel }\end{array}$ & $\begin{array}{c}\text { Rice-field } \\
\text { plot }\end{array}$ & Both \\
\hline Proteus mirabilis & - & - & 08 \\
Proteus rettgeri & 02 & - & - \\
Proteus vulgaris & - & - & 05 \\
Proteus penneri & 01 & - & - \\
Enterobacter cloaceae & - & - & 06 \\
Enterobacter sp. & - & - & 08 \\
Citrobacter sp. & - & - & 16 \\
Salmonella sp. & 03 & - & - \\
Escherichia coli & - & - & 04 \\
Klebsiella sp. & 01 & - & - \\
Shigella spp. & 01 & - & - \\
Ochrobactrum anthropi & - & - & 06 \\
Stenotrophomonas maltophilia & - & - & 07 \\
Burkholderia cepacia & - & - & 03 \\
Pantoea spp. 1 & - & - & 03 \\
Pantoea spp. 2 & 01 & - & - \\
Pantoea spp. 3 & - & 01 & - \\
Pseudomonas aeruginosa & - & 01 & - \\
Pasteurella pneumotropica & - & - & 04 \\
Aeromonas hydrophila & 01 & - & - \\
Bacillus sp. & - & - & 124 \\
Micrococcus sp. & - & - & 14 \\
Staphylococcus sp. & - & - & 29 \\
Corynebacterium sp. & - & - & 48 \\
Lactobacillus sp. & & & 18 \\
\hline & & &
\end{tabular}

The isolates belonged to 19 genera (Fig. 1), including those with low frequency $(0.3 \%)$, such as Klebsiella, Shigella, Pseudomonas and Aeromonas. The Bacillus genus presented the highest frequency (39\%), followed by Corynebacterium (15\%); Lactobacillus and Proteus (11\%); Staphylococcus, Micrococcus and Enterobacter (9\%). The following genera were detected with frequencies between $2 \%$ and 5\%: Citrobacter; Pantoea; Pasteurella; Escherichia; Stenotrophomonas; Burkholderia; Salmonella and Ochrobactrum.

There was no significant difference among the microbial diversity in the five rice crop regions $\left(\mathrm{F}_{4,12}=1.04 ; \mathrm{P}>0.05\right)$. In regard to the water from the irrigation channel and the rice crop plots, diversity was significantly greater in the first treatment $\left(\mathrm{F}_{1,12}=6.88 ; \mathrm{P}<0.05\right)$. There was no significant difference between bacterial species occurrence in the initial $\left(\mathrm{P}_{1}\right)$ and final $\left(\mathrm{P}_{2}\right)$ phases of the cultivation cycle $\left(\mathrm{F}_{1,12}=4.25 ; \mathrm{P}>0.05\right)$. The interactions between treatment (channel and plot) and cultivation phases $\left(\mathrm{P}_{1}\right.$ e $\mathrm{P}_{2}$ ) did not affect the diversity of bacterial species.

The Gram-positive rods represented by Bacillus, Corynebacterium and Lactobacillus genera were found homogeneously distributed in all regions and treatments. The first genus was the prevalent bacterial group, and its density and distribution throughout the five rice crop regions are shown in Fig. 2A.

The three most frequent genera in the water samples from the channels and the rice plots were Bacillus, Corynebacterium and Staphylococcus, followed by Lactobacillus, Proteus, Citrobacter, Micrococcus and Enterobacter. In other studies to assess soil diversity in tropical regions Bacillus, Micrococcus and Enterobacter genera were found, being the latest the most abundant genera, but Lactobacillus genus was detected as well (23).

There are many saprophyte species included in the Bacillus group. These bacteria are able to remain latent, which provides them adaptive characteristics to many environments (20), with mesophilic and thermophilic environments showing the greatest probability to the occurrence of the Bacillus genus (24). Environmental conditions of temperature for rice crops in tropical climates do not exceed $36^{\circ} \mathrm{C}(9)$.

The Corynebacterium genus showed greater affinity with the water environment of the rice irrigation channel. Lactobacillus was present both in the channel and in the rice crop plot. According to Buchanan et al. (4) and Pelczar et al. (20), Corynebacterium species belong to three separate sections: pathogens of animals and humans, where $C$. diphtheriae is the most noticeable; Corynebacterium pathogenic to plants, and non-pathogenic Corynebacterium.

In regard to the Gram-positive cocci, mainly Staphylococcus (Fig. 2B) and Micrococcus (Fig. 2C) genera, they showed the same distribution as the Gram-positive rods. However, Micrococcus was prevalent in water from the irrigation channel, free from phytosanitary treatments of the plowing field.

For irrigation of the rice crop fields, rivers, lakes and dams were used as water sources. Due to their great anthropic influence, several bacteria of the Enterobacteriaceae family were found. In this study, the presence of enterobacteria was noticed both in the

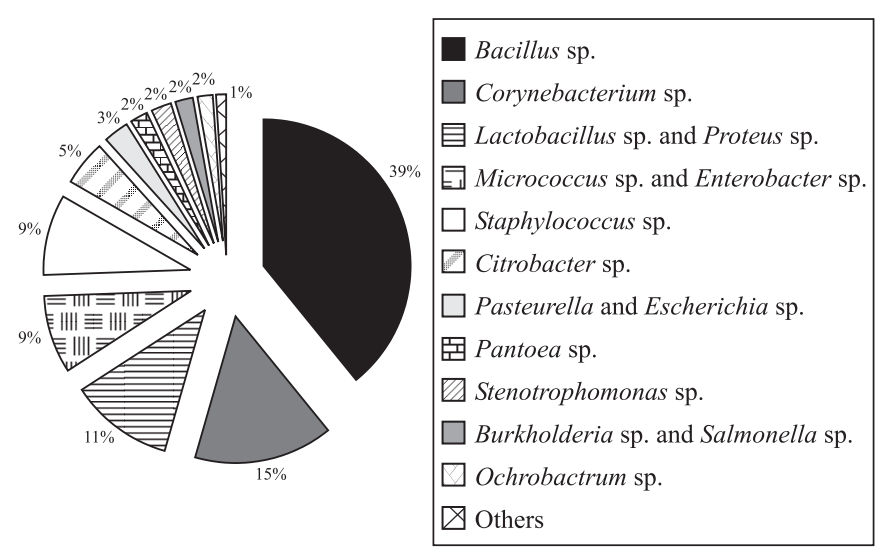

Figure 1. Diversity of bacteria identified in water samples from various rice crop areas in Rio Grande do Sul State, Brazil. 


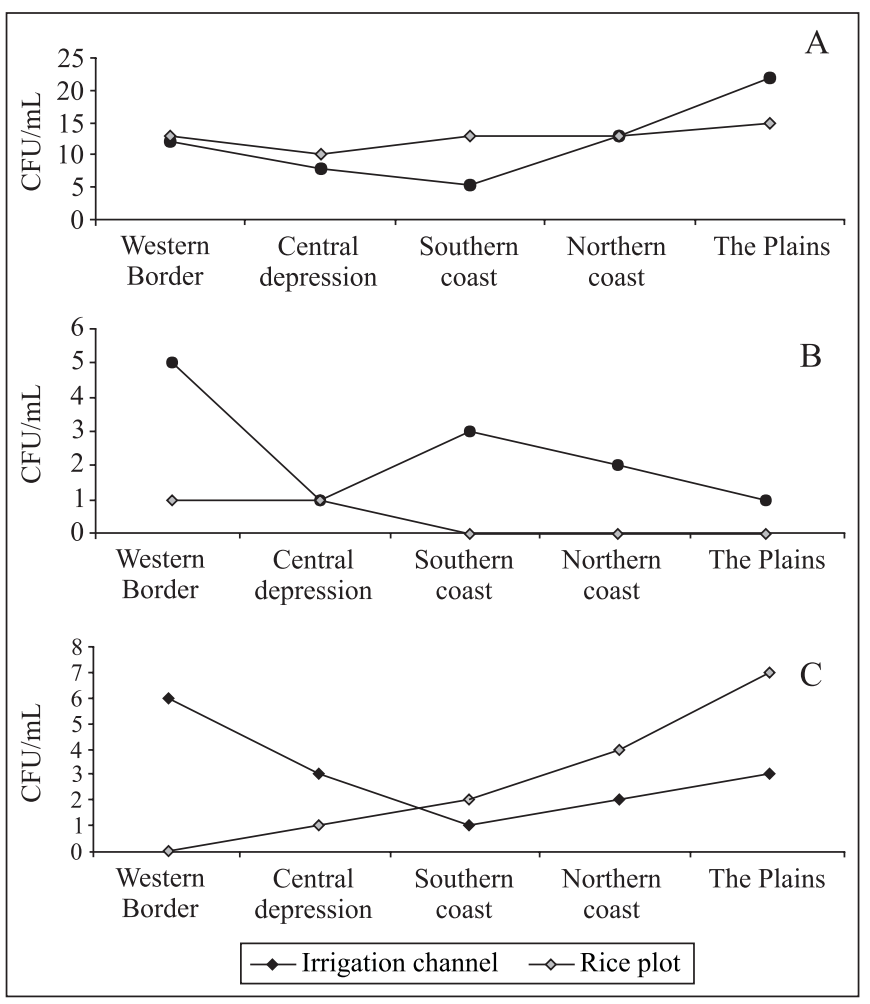

Figure 2. Density and distribution of Bacillus spp. (A), Micrococcus spp. (B) and Staphylococcus spp. (C) in flooded rice growing areas in Rio Grande do Sul State, Brazil.

rice growing plots and in the irrigation channels, being more prevalent in the later ones. These are ubiquitous microorganisms found in soil, water and vegetation and are part of the normal intestinal microbiota of the majority of animals and humans (17). Increase in the prevalence of this bacterial group in water bodies is ascribed to the throwing of organic matter of diverse origins into the water, mainly non-treated fecal matter (20). Cho and Kim (6) in Korea confirmed an increase in bacterial diversity when aquifers were contaminated with effluents containing animals' excrement. Enterobacter cloaceae, Citrobacter freundii, Burkholderia cepaceae, Klebsiella oxytoca, Stenotrophomonas maltophilia and Shigella sp. also occurred in the water samples of this study, although Shigella and Klebsiella were less prevalent in the rice crop regions. Investigating of the microbiota of the conjunctive of clinically normal individuals working in hospitals, Trindade et al. (25) found Proteus, Enterobacter and Citrobacter, which were species not known to be part of the normal microbiota of the conjunctive. These authors also mentioned that Enterobacter, Klebsiella and Pseudomonas can grow actively in water, being Pseudomonas able to reproduce even in distillate water. These observations agree with the findings of the present study, in which $P$. aeruginosa was detected in the water that irrigates the rice field plot located in the Western Border area.
Species of Ochrobactrum and Pantoea were found in all regions, specially in those submitted to treatment with agrochemicals. Pantoea, Bacillus, Enterobacter, Micrococcus and Pseudomonas are among the main genera found in the spermosphere microbiome, where one can find plant pathogens such as Corynebacterium sp. and Pseudomonas sp., which infect seeds or other materials (13).

The Burkholderia genus was identified only in water samples from the irrigation channel and the rice crop plots of the Southern Coast. Isolates from that genus have been detected in rice plants in Brazil and Vietnam, being classified as diazotrophic endophytic microorganism, previously included in the Pseudomonas genus (18).

In this study Stenotrophomonas sp. was detected in both treatments and in three rice growing regions: Western Border, Central Depression and Southern Coast. The Stenotrophomonas maltofilia species is settled in many environments and can be isolated from water, soil, debris, raw milk, frozen fish and disinfection solutions used in hospitals (7). Many isolates were detected in nosocomial environments, in equipment, tap water and hands, being an opportunistic pathogen that colonizes the upper respiratory tract and can cause infections.

The occurrence of Aeromonas hydrofila in the water of the rice irrigation channel in growing fields in RS can be probably due to an abundance of organic material in those waters. Bacterial survival in water ecosystems can be defined as the cellular state that results from their presence in a hostile environment where microbial predation, nutrients' insufficiency, inadequate physical conditions, occasional toxins and naturally or anthropogenic produced biocides coexist or interact (2).

In this study, it was noticed that water from the irrigation channel showed greater diversity $\left(H^{\prime}=1.00\right)$ than the rice-field $\operatorname{plot}\left(\mathrm{H}^{\prime}=0.77\right)$. The channel showed a more uniform distribution of the species $(e=0.73)$ while the plot $(e=0.59)$ showed the prevalence of the Bacillus genus. The regions and the cultivation phases did not affect significantly the bacterial diversity in the studied areas, the diversity was greater in the Western Border and lower in the initial phases $\left(\mathrm{P}_{1}\right)$.

In regard to the bacterial species present in rice crop regions, certain homogeneity was observed in the Plains and the Northern Coast. A second group encompassed the Western Border and the Central Depression. The Southern Coast was the most heterogeneous if compared to the other regions.

The results of this research can be the basis for the qualitative analysis of the bacterial diversity in water, its environmental impact and its influence on the functional processes of the bacteria of this agroecosystem. Microorganisms (Prokaryotes) can interact with plants grown in flooded areas (Oryza sativa) decreasing the environmental impact of the use of agrochemicals in cultivation management. In addition plants can work as mediators of the purification processes of waters contaminated with pathogenic microorganisms. 


\section{ACKNOWLEDGEMENTS}

This work was conducted with the cooperation of EEA/ IRGA and UNISINOS and with the financial support of CAPES. We would like to thank the technical team of EEA/IRGA, for help in the collection of the water samples and Mr. Cláudio Luiz Silva (bioMérieux) for his technical support.

\section{RESUMO}

\section{Diversidade de bactérias em água de orizicultura do Rio Grande do Sul}

As bactérias são as mais diversas formas de vida na terra e somente uma fração dessas espécies têm sido identificadas. Esse trabalho objetivou a análise da diversidade de bactérias mesófilas, heterotróficas presentes em amostras de água de irrigação de lavouras de arroz do Estado do Rio Grande do Sul, Brasil. As amostras foram coletadas em cinco regiões produtoras de arroz, sendo em seguida o isolamento, a multiplicação e a caracterização bacteriana. A identificação das espécies foi baseada em testes bioquímicos (Sistema API, bioMérieux). A diversidade bacteriana foi determinada pelo índice de Shannon $\&$ Weaner e Pielou. Os resultados obtidos quanto a diversidade de bactérias revelaram 26 espécies. Representantes dos gêneros Bacillus, Corynebacterium, Staphylococcus e Lactobacillus foram os mais abundantes com uma distribuição homogênea em todas as regiões orizícolas estudadas, assim como nas áreas correspondentes ao canal de irrigação e a parcela de cultivo do arroz. A água do canal de irrigação apresentou maior diversidade $\left(H^{\prime}=1,00\right)$ quando comparada à parcela $\left(H^{\prime}=0,77\right)$. O canal também apresentou uma distribuição mais uniforme das espécies $(e=0,73)$ enquanto a parcela $(e=0,59)$ teve a maior dominância que foi representada pelo gênero Bacillus. As regiões e as fases da cultura não influenciaram significativamente à diversidade bacteriana nas áreas de estudo $\left(\mathrm{F}_{4,12}=1,04 ; \mathrm{P}>0,05\right)$. Os resultados revelam que o manejo da cultura pode influenciar nas populações bacterianas da água.

Palavras-chave: bactérias, diversidade, água, orizicultura

\section{REFERENCES}

1. Azevedo, J.L. Biodiversidade microbiana e potencial biotecnológico In: Melo, I.S. e Azevedo, J.L. (ed.). Ecologia Microbiana. EMBRAPA - CNPMA, Jaguariúna, 1998, p.445-486.

2. Barcina, I.; Lebaron, P.; Vives-Rego, J. Survival of allochthonous bacteria in aquatic systems: a biological approach. Microbiol. Ecol., 23, 1-9, 1997

3. Boone, D.R.; Castenholz, R.W. The Archaea and the Deeply Branching and Phototrophic Bacteria. In: Garrity, G.M. (ed.). Bergey's Manual of Systematic Bacteriology. Springer-Verlag, New York, 2001, p.721.

4. Buchanan, R.E.; Gibbons, N.E.; Cowan, S.T., Holt, J.G., Liston, J.; Murray, R.G.E.; Niven, C.F.; Ravin, A.W.; Stanier, R.Y., 1974,
Bergey's Manual of Determinative Bacteriology. 8ed. William \& Wilkins, Baltimore, $1268 \mathrm{p}$.

5. Brower, J.E.; Zar, J.H. Field \& laboratory methods for general ecology. W.C. Brown Publishers. Dubuque, Iowa, 1984, 226p.

6. Cho, J.; Kim, S. Increase in bacterial comunity diversity in subsurface aquifers receiving livestock wastewater imput. Appl. Environ. Microbiol., 66, 956-965, 2000.

7. Garcia, D.O.; Timenetsky, J.; Martinez, M.B.; Francisco, W.; Sinto, S.I.; Yanaguita, R.M. Protease (Caseinase and Elastase), hemolysins, adhesion and susceptibility to antimicrobials of Stenotrophomonas maltophilia isolates obtained from clinical specimens. Braz. J. Microbiol., 33, 157-162, 2002.

8. Haines, J.R.; Herrmann, R.; Lee, K.; Cobanli, S.; Blaise, C. Microbial population analysis as a measure of ecosystem restoration. Biorremed. J., 6(3), 283-296, 2002.

9. IRGA - Intituto Riograndense do Arroz/Estação Experimental do Arroz. Arroz Irrigado: recomendações técnicas de pesquisa para o Sul do Brasil. Cachoeirinha, 2001. 128p.

10. Kennedy, A.C. Bacterial diversity in agroecosystems. Agric. Ecosyst. Environ., 74:65-76, 1999.

11. Kirchman, D.L. The ecology of Cythophaga-Flavobacteria in aquatic environments. FEMS Microbiol. Ecol., 39, 91-100, 2002.

12. Koneman, E.M.; Allen, S.D.; Janda, W.M.; Schereckenberguer, P.C.; Winn, W.C. Diagnóstico microbiológico Texto y Atlas color. Editorial Medica Panamericana, Buenos Aires, 1999, 1432p.

13. Luz, W.C. Ecologia da espermosfera. In: Melo, I.S.; Azevedo, J.L. (ed.). Ecologia Microbiana. EMBRAPA - CNPMA, Jaguariúna, 1998, p.167-187.

14. Mc Faddin, J.F. Pruebas bioquimicas para la identificacion de bacterias de importancia clinica. Panamericana, Buenos Aires, 1984, p.11-301.

15. Mohanty, S.R.; Bharati, K.; Deepa, N.; Rao, V.R.; Adhya, T.K. Influence of heavy Metals on Methane Oxidation in tropical rice soils. Ecotoxicol. Environ. Saf., 47, 277-284, 2000.

16. Moraes, J.C.; Fontoura, M.M.C.; Benvegnú, S.A. Microbiologia: atividades práticas. Pe. Berthier, Passo Fundo, 1999, 208 p.

17. Murray, P. R.; Rosenthal, K.S.; Kobayashi, G. S.; Pfaller, M.A. Microbiologia Médica. Guanabara-Koogan, São Paulo, 1998, 406p.

18. Neves, M.C.P.; Rumjanek, N.G. Ecologia das bactérias diazotróficas nos solos tropicais. In: Melo, I.S.; Azevedo, J.L. (ed.). Ecologia Microbiana. EMBRAPA - CNPMA, Jaguariúna, 1998, p.15-60.

19. Odum, E.P. Ecologia. Guanabara Koogan S.A, Rio de Janeiro, 1985, $434 \mathrm{p}$

20. Pelczar, J.M.; Chan, E.C.S.; Krieg, N.R. Microbiologia: Conceitos e Aplicações. Makron Books, São Paulo, 1996, 524-517p.

21. Rikhvanov, E.G.; Varakina, N.N.; Sozinov. D.Y.; Voinikov, V.K. Association of bacteria and yeasts in hot springs. Appl. Environ. Microbiol., 65, 4292-4293, 1999.

22. Shannon, C.E.; Wiener, W. The mathematical theory of communication. University of Illinois Press, Urbana, Illinois, USA. 1949, 117p.

23. Silva, P.; Nahas, E. Bacterial Diversity in soil in response to different plants, phosphate fertilizers and liming. Braz. J. Microbiol., 33, 304-310, 2002.

24. Souza, A.N.; Martins, M.L.L. Isolation, properties and kinetics of a thermophilic Bacillus. Braz. J. Microbiol., 32, 271-275, 2001.

25. Trindade, R.C.; Bonfim, A.C.R.; Resende, M.A. Conjunctival microbial flora of clinically normal persons who work in a hospital environment. Braz. J. Microbiol., 31, 12-16, 2000.

26. Villar, P.M.D. Tendências da produção e do mercado mundial de arroz. $1^{\circ}$ Congresso da Cadeia Produtiva de Arroz, Florianópolis, 2002, p.111-114.

27. Yamaoka-Yano, D.M.; Valarini, P.J. Métodos de identificação de Bactérias. In: Melo, I.S.; Azevedo, J.L. (ed.). Ecologia Microbiana. EMBRAPA - CNPMA, Jaguariúna, 1998, p. 369-419.

28. Zar, J.H. Biostatistical Analysis. Prentice-Hall International, New Jersey, 1999, 931p. 